\title{
Changes in Water and Sediment Quality of a River Being Impounded and Differences Among Functional Zones of the New Large Tropical Hydroelectric Reservoir
}

\author{
Teck-Yee Ling ${ }^{1 *}$, Chen-Lin Soo ${ }^{2}$, Chui-Ping Kho ${ }^{1}$, Lee Nyanti ${ }^{1}$, Siong-Fong Sim ${ }^{1}$, \\ Karen-Suan-Ping Lee ${ }^{3}$, Tonny Ganyai ${ }^{3}$ \\ ${ }^{1}$ Faculty of Resource Science and Technology, University Malaysia Sarawak, Sarawak, Malaysia \\ ${ }^{2}$ Institute for Tropical Biology and Conservation, Universiti Malaysia Sabah, Jalan UMS, \\ 88400 Kota Kinabalu, Sabah, Malaysia \\ ${ }^{3}$ Research and Development Department, Sarawak Energy Berhad, Sarawak, Malaysia
}

Received: 6 June 2018

Accepted: 8 October 2018

\begin{abstract}
Though more large tropical reservoirs are being constructed to meet the increasing energy demand, knowledge on the impact of damming a tropical river and the differences along the river after its impoundment is scarce. Thus, the present study aimed to increase our understanding of such differences both longitudinally and vertically. Water and sediment samples were collected at three different functional zones in the Murum River basin 10 months after impoundment began. Results show that the impoundment has an impact on both the water and sediment. Longitudinal variations of water and sediment characteristics were observed at different functional zones. The upstream riverine zone subjected to anthropogenic activities serves as the main input of suspended solids and nutrients to the reservoir. The nitrogen changed from a high nitrate and low ammonia condition prior to impoundment to a low nitrate and high ammonia condition due to the accumulation of organic matter and slow nitrification rate after impoundment. In the transitional and lacustrine zones, vertical stratifications of dissolved oxygen and temperature were observed. The thickness of a well-oxygenated column for sensitive aquatic organisms was only $2 \mathrm{~m}$ at some stations. Water quality in all zones showed impairment during the filling phase as compared to the good water quality index before impoundment. The reduction of suspended solids in the surface water column in the transitional and lacustrine zones is a positive change for aquatic organisms. Sediment characteristics were found to be distinct in the transitional zone, where it was lower in sand and higher in silt, clay, organic carbon and nutrients in contrast to the riverine
\end{abstract}

*e-mail: tyling@unimas.my 
zone. Clay increased in all zones after the impoundment. There is an urgent need to reduce the pollutants input from the upstream riverine zone.

Keywords: dam, impoundment, longitudinal variations, Murum River, nutrients

\section{Introduction}

Impoundment and its associated negative impacts on the river have been well documented [1-3]. Studies have shown that a new reservoir is even more prone to eutrophication than an old one [4]. As the condition of a new reservoir significantly influences its functions in the future and has impacts on the surrounding environment, research conducted on a new reservoir is novel and necessary, particularly a large reservoir in a tropical area like Malaysia, which has a higher potential for environmental degradation given the higher propensity to hypoxia in the deeper layers [5]. Recently, Nyanti et al. [6] reported that the dissolved oxygen content dropped to anoxic condition at depths of 1 to $4 \mathrm{~m}$ during the filling phase of the large tropical Bakun Reservoir, which is also located in Sarawak on Borneo Island. However, no sediment quality study of Bakun reservoir was conducted during the filling phase. For the newly formed large Murum Dam Reservoir just upstream of Bakun Dam, little is known about the water and sediment quality.

In a reservoir, studies are often conducted along the riverine-transitional-lacustrine zones as the reservoir transits from lotic to lentic habitat $[7,8]$. The riverine zone is a shallow unstratified portion located closest to the inflowing river and furthest from the dam, whereas the lacustrine zone is the stable stratified lake-like area nearest the dam. This spatial diversity can lead to riverine-transitional-lacustrine gradients in various water and sediment characteristics. A longitudinal decrease in water quality from upstream to downstream was observed in a refilled hydroelectric reservoir in Belgium, whereby the longitudinal variations were attributed to the water residence time and bottom morphology of the reservoir, and their impacts on nutrient distribution in the reservoir [9]. On the other hand, there was no marked variation among the sampling sites in a small hydropower plant reservoir in southern Brazil due to the short water residence time [10]. Nevertheless, it was reported that during a period of increased residence time, the site nearest to the dam exhibited poor water quality.

The second largest hydroelectric dam in Sarawak, Murum Dam, was constructed across the Murum River, a tributary of Batang Balui where the Bakun Dam is located. The assessment of water and sediment characteristics of the Murum Reservoir at different functional zones during its filling phase is vital for immediate mitigation measures if deterioration has occurred in the reservoir. The data obtained could also serve as a baseline for future reference when the reservoir becomes mature over time and as it ages and also for future dams which are to be built. Hence, the objectives of the present study were to determine the water and sediment quality of the Murum Reservoir at three different functional zones after the filling process of approximately 10 months.

Table 1. The details of the sampling regime and sampling location surveyed in the present study.

\begin{tabular}{|c|c|c|c|c|c|}
\hline Zone & Station & GPS Coordinates & Sampling Date & $\begin{array}{l}\text { Depth } \\
(\mathrm{m})\end{array}$ & Location \\
\hline \multirow{3}{*}{$\begin{array}{l}\text { Riverine } \\
\text { (upstream) }\end{array}$} & St 1 & N02³9’03.6” E114³6’24.1”' & $7^{\text {th }}$ July 2014 & 7.4 & Upstream of the Plieran River \\
\hline & St 2 & N02²8’39.8” E11447’34.7”' & $8^{\text {th }}$ July 2014 & 3.5 & Upstream of the Danum River \\
\hline & St 3 & N02²8'12.2” E11446’51.4” & $9^{\text {th }}$ July 2014 & 0.5 & $\begin{array}{c}\text { Upstream of a tributary of the Danum } \\
\text { River }\end{array}$ \\
\hline \multirow{2}{*}{ Transitional } & St 4 & $\mathrm{~N} 02^{\circ} 39^{\prime} 30.5^{\prime \prime} \mathrm{E} 114^{\circ} 35^{\prime} 03.2^{\prime \prime}$ & $7^{\text {th }}$ July 2014 & 34.0 & Approximately $15 \mathrm{~km}$ downstream of St 1 \\
\hline & St 5 & N02³0'29.9” E114³9’07.4”' & $8^{\text {th }}$ July 2014 & 28.0 & Approximately $15 \mathrm{~km}$ downstream of St 2 \\
\hline \multirow{3}{*}{ Lacustrine } & St 6 & N02³8’27.4” E114²4’41.1” & $7^{\text {th }}$ July 2014 & $>79.0^{*}$ & $\begin{array}{c}\text { Confluence of the Plieran River and } \\
\text { Danum River }\end{array}$ \\
\hline & St 7 & N02³9’41.8” E114²1’49.5” & $7^{\text {th }}$ July 2014 & $>79.0^{*}$ & In front of the dam wall \\
\hline & St 8 & N0241’03.1” E114²19’00.1” & $7^{\text {th }}$ July 2014 & 45.7 & Water intake point \\
\hline $\begin{array}{c}\text { Riverine } \\
\text { (downstream) }\end{array}$ & St 9 & N02³8'50.1” E114²2’54.5” & $8^{\text {th }}$ July 2014 & $<0.5^{* *}$ & Downstream of the dam and spillway \\
\hline
\end{tabular}

*above the detection limit of depth sounder

**below the detection limit of depth sounder 


\section{Materials and Methods}

\section{Study Area and Site Description}

The large Murum Hydroelectric Reservoir is located in the Belaga District, Kapit Division, in the northeastern part of Sarawak, Malaysia. It lies on the Murum River, a tributary of the Balui in the uppermost part of the Rajang River basin. It is about $42 \mathrm{~km}$ upstream of Bakun Dam. The construction of the dam began in 2008 and the filling of the reservoir was initiated in 2013. When the sampling was conducted in July 2014 the water level of the reservoir had reached $527 \mathrm{~m}$ above sea level. Forest clearing, including logging activities and burning of the cut vegetation surrounding the reservoir, was observed during the sampling trip.

The $53 \mathrm{~m}$ tall water intake tower is connected to a powerhouse via a $2680 \mathrm{~m}$ twin tunnels with surge tanks. An ecological power house (EPH) with two installed turbines was also constructed to ensure that the ecosystem of the upper reaches of the Murum River remain active [11]. The intake invert entrance level and outlet level of the EPH were at $508 \mathrm{~m}$ and $413 \mathrm{~m}$ above sea level, respectively, with a discharge rate of $2 \times 3.9 \mathrm{~m}^{3} / \mathrm{s}$. The spillway of the Murum Reservoir was located at $540 \mathrm{~m}$ above sea level. The height and crest length of the spillway are $130 \mathrm{~m}$ and $54 \mathrm{~m}$, respectively, with a maximum capacity of $2160 \mathrm{~m}^{3} / \mathrm{s}$. It is an uncontrolled spillway where it does not have any gate. When the water rises above the lip or crest of the spillway it begins to spill water from the reservoir and the spilt water is mixed with the outflow from EPH for the downstream river.
In the present study, the Murum Reservoir was divided into three functional zones: riverine, transitional, and lacustrine. A total of nine sampling stations were selected in the present study (Table 1). Three stations were located in the riverine zone of the reservoir where station 1 was located at the Plieran River, while stations 2 and 3 were at the Danum River and its tributary, respectively (Fig. 1). Stations 4 and 5 were located in the transitional zone of the Plieran and Danum rivers, respectively. Three stations were located in the lacustrine zone of the reservoir where station 6 was located at the confluence of the Plieran and Danum rivers, station 7 was located near the dam, and station 8 was located near the water intake point. Finally, one station (station 9) was located at the downstream river, which was about $7.4 \mathrm{~km}$ from the dam, under Murum Bridge. During the filling phase, the downstream river of the reservoir was supplied with a $10 \%$ base flow for the protection of aquatic organisms downstream. At sampling time, the water at station 9 was about half a meter deep.

\section{Sample Collection and Analysis}

Field sampling was conducted 7-9 July 2014, approximately 10 months after the filling of the reservoir was initiated. The sampling regime was summarized in Table 1. It was conducted during the dry season with little or no rainfall $(0-17.4 \mathrm{~mm})$ throughout the sampling month according to the Malaysian Meteorological Department of Sarawak branch. Water samples in the riverine zone were taken from the surface $(30-40 \mathrm{~cm})$, whereas water samples in the transitional and lacustrine zones were collected at three different depths (surface,

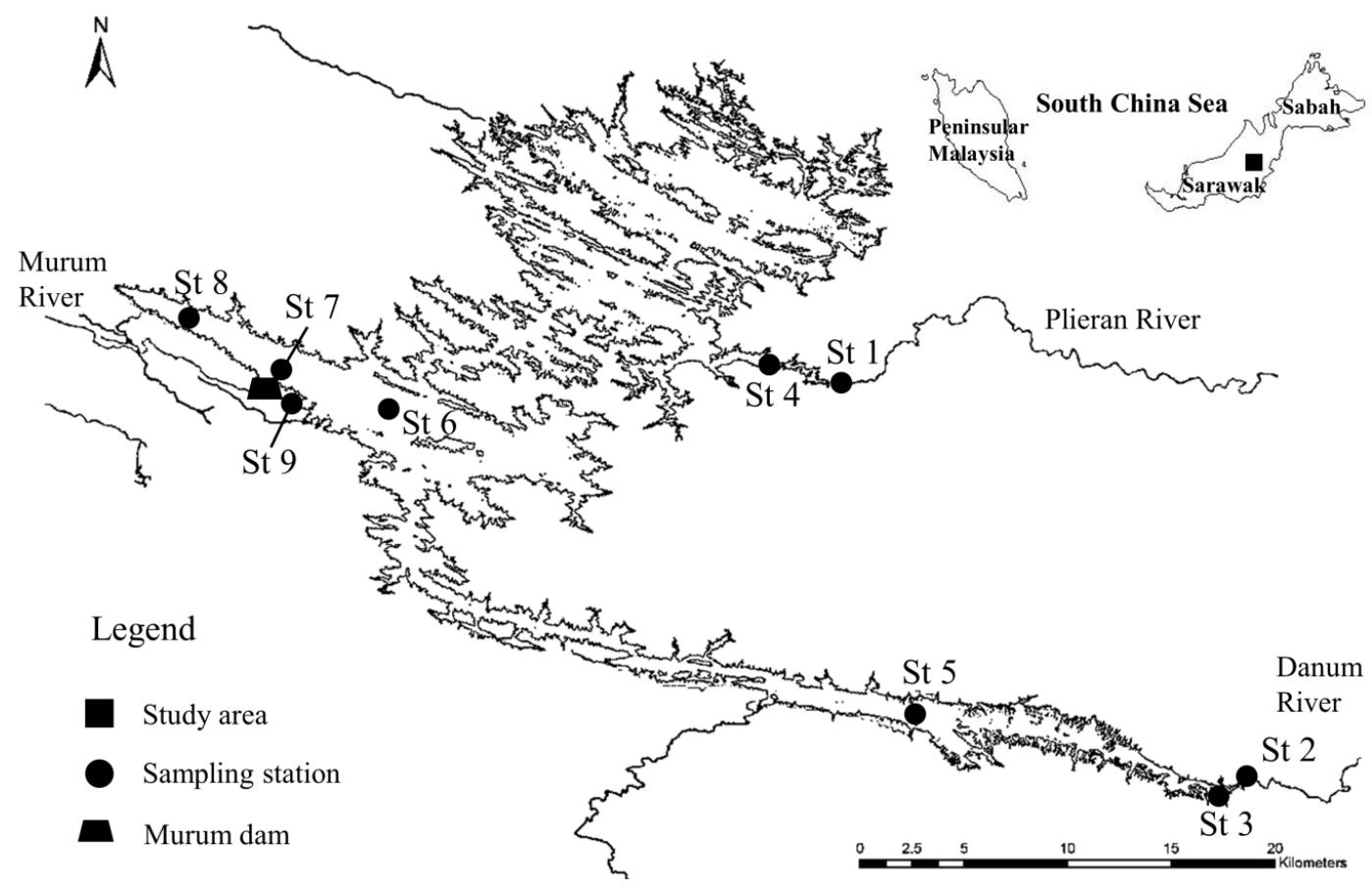

Fig. 1. The Murum reservoir which is located in Sarawak state and location of nine sampling stations in the reservoir. 
Table 2. Analytical methods of the physical-chemical parameters in the present study.

\begin{tabular}{|c|c|}
\hline Parameters & Instrument/Method \\
\hline \multicolumn{2}{|c|}{ Depth profile } \\
\hline Water temperature $\left({ }^{\circ} \mathrm{C}\right)$ & DO meter (Pro 20, YSI) \\
\hline Dissolved oxygen (mg/L) & DO meter (Pro 20, YSI) \\
\hline \multicolumn{2}{|c|}{ Onsite measurements } \\
\hline Water temperature $\left({ }^{\circ} \mathrm{C}\right)$ & $\begin{array}{l}\text { Multiparameter sonde } \\
\text { (YSI6920) }\end{array}$ \\
\hline Dissolved oxygen (mg/L) & $\begin{array}{l}\text { Multiparameter sonde } \\
\text { (YSI6920) }\end{array}$ \\
\hline $\mathrm{pH}$ & $\begin{array}{c}\text { pH meter (T19000 WalkLab, } \\
\text { Trans) }\end{array}$ \\
\hline Conductivity $(\mu \mathrm{S} / \mathrm{cm})$ & $\begin{array}{l}\text { Conductivity meter (Cyber- } \\
\text { Scan Con 11, Eutech) }\end{array}$ \\
\hline Turbidity (FTU) & $\begin{array}{l}\text { Turbidity meter (ELE Interna- } \\
\text { tional, Hanna) }\end{array}$ \\
\hline Transparency (m) & $\begin{array}{l}\text { Secchi disc with a measuring } \\
\text { tape }\end{array}$ \\
\hline Depth (m) & $\begin{array}{l}\text { Depth sounder (PS-7, Hon- } \\
\text { dex) }\end{array}$ \\
\hline Velocity (m/s) & Flow meter (Geopacks) \\
\hline \multicolumn{2}{|c|}{ Laboratory measurements (water sample) } \\
\hline Chlorophyll $a\left(\mathrm{mg} / \mathrm{m}^{3}\right)$ & $\begin{array}{l}\text { Spectrophotometric method } \\
{[14]}\end{array}$ \\
\hline Total suspended solids $(\mathrm{mg} / \mathrm{L})$ & Oven drying method [14] \\
\hline $\begin{array}{l}\text { Five-day biochemical oxygen } \\
\text { demand }(\mathrm{mg} / \mathrm{L})\end{array}$ & 5-day BOD test [14] \\
\hline $\begin{array}{l}\text { Chemical oxygen demand } \\
(\mathrm{mg} / \mathrm{L})\end{array}$ & $\begin{array}{l}\text { Closed reflux, titrimetric } \\
\text { method [13] }\end{array}$ \\
\hline Total phosphorus(mg/L) & $\begin{array}{l}\text { Persulfate digestion, ascorbic } \\
\text { acid method }[13,14]\end{array}$ \\
\hline Inorganic phosphorus (mg/L) & Ascorbic acid method [13] \\
\hline Total nitrogen $(\mathrm{mg} / \mathrm{L})$ & $\begin{array}{l}\text { Persulfate digestion, cadmium } \\
\text { reduction method }[13,14]\end{array}$ \\
\hline Ammonia-nitrogen (mg/L) & Salicylate method [13] \\
\hline Nitrite-nitrogen (mg/L) & $\begin{array}{l}\text { Diazotization method (low } \\
\text { range) [13] }\end{array}$ \\
\hline Nitrate-nitrogen(mg/L) & $\begin{array}{l}\text { Cadmium reduction method } \\
{[13]}\end{array}$ \\
\hline \multicolumn{2}{|c|}{ Laboratory measurements (sediment sample) } \\
\hline Particle size analysis $(\%)$ & Pipette method [15] \\
\hline $\mathrm{pH}$ & $\begin{array}{l}\text { pH meter (Orion } 3 \text { Star, } \\
\text { Thermo Scientific) [16] }\end{array}$ \\
\hline Organic matter (\%) & Loss-On-Ignition method [17] \\
\hline Total organic carbon $(\%)$ & Walkley-Black method [17] \\
\hline Total phosphorus (mg/kg) & $\begin{array}{l}\text { Perchloric digestion, ascorbic } \\
\text { acid method [18] }\end{array}$ \\
\hline $\begin{array}{l}\text { Total Kjeldahl nitrogen } \\
(\mathrm{mg} / \mathrm{kg})\end{array}$ & $\begin{array}{c}\text { Digestion, distillation, Nessler } \\
\text { method }[13,14]\end{array}$ \\
\hline
\end{tabular}

$10 \mathrm{~m}$ and $20 \mathrm{~m}$ ). Surface water samples were collected by slowly submerging into the surface water column a $1.2 \mathrm{~L}$ acid-washed polyethylene bottle and retrieving from it. Water at $10 \mathrm{~m}$ and $20 \mathrm{~m}$ depths were sampled using a 3.2 L horizontal, PVC Van Dorn bottle (Wildco, BetaTM) before pouring into a $1.2 \mathrm{~L}$ acid-washed polyethylene bottle.

In situ parameters including temperature, $\mathrm{DO}, \mathrm{pH}$, conductivity, turbidity, transparency, depth, and velocity were measured during water sample collection (Table 2). Flow velocity was measured at stations 1,2 , and 3, which were located in the riverine zone. Total discharge, mean velocity, and mean depth were calculated according to Chapra [12]. The study of depth profiles of temperature and DO were conducted at stations $1,2,4,5,6,7$, and 8. Triplicate water samples were collected for the analyses of chlorophyll $a(\operatorname{chl} a)$, total suspended solids (TSS), five-day biochemical oxygen demand $\left(\mathrm{BOD}_{5}\right)$, chemical oxygen demand (COD), total phosphorus (TP), inorganic phosphorus (Inorg-P), total nitrogen (TN), ammonia-nitrogen (TAN), nitrite-nitrogen $\left(\mathrm{NO}_{2}-\mathrm{N}\right)$, and nitrate-nitrogen $\left(\mathrm{NO}_{3}-\mathrm{N}\right)$. Water samples were placed in an ice box and analyzed immediately after sampling. All the water quality analyses were conducted in triplicate according to the Standard Methods summarized in Table 2. A calibration curve was constructed for each chemical analysis. The blank and standard solutions were treated in the same way as the sample. The submerged sediment sample was collected near the riverbank or reservoir bank, approximately $30 \mathrm{~cm}$ below the surface water by using a scoop. The sample was placed in a labeled plastic bag and stored in an ice box for further analysis of sediment $\mathrm{pH}$, soil texture, organic matter (OM), total organic carbon (TOC), total phosphorus (TP), and total Kjeldahl nitrogen (TKN). Sediment samples were air-dried before analysis. All the sediment analyses were conducted in triplicate except for particle size analysis, which was conducted in duplicate.

\section{Water Quality Index (WQI)}

Water quality index (WQI), which combines six variables of $\mathrm{DO}, \mathrm{BOD}, \mathrm{COD}, \mathrm{TSS}, \mathrm{AN}$, and $\mathrm{pH}$, was calculated with the following equation:

$$
\begin{aligned}
W Q I= & 0.22 \times S I_{D O}+0.19 \times S I_{B O D}+0.16 \times S I_{C O D}+0.15 \times \\
& \times S I_{A N}+0.16 \times S I_{S S}+0.12 \times S I_{p H}
\end{aligned}
$$

...where SI indicates the subindex for each parameter, where SIDO is the subindex for DO ( $\%$ saturation), SIBOD is the subindex for BOD $(\mathrm{mg} / \mathrm{L})$, SICOD is the subindex for COD $(\mathrm{mg} / \mathrm{L})$, SIAN is the subindex for AN $(\mathrm{mg} / \mathrm{L})$, SISS is the subindex for SS $(\mathrm{mg} / \mathrm{L})$, and $\mathrm{SIpH}$ is the subindex for $\mathrm{pH}$ [19]. The calculated WQI was then classified according to the WQI classification (Table 3) to assess the pollution status of each station. 
Table 3. Water Quality Index (WQI) Classification in Malaysia [24].

\begin{tabular}{|c|c|c|c|c|c|c|c|}
\hline Classification & SIDO & SIBOD & SICOD & SISS & SIAN & SIpH & WQI \\
\hline Class I & $>7$ & $<1$ & $<10$ & $<25$ & $<0.1$ & $>7$ & $>92.7$ \\
\hline Class II & $5-7$ & $1-3$ & $10-25$ & $25-50$ & $0.1-0.3$ & $6-7$ & $76.5-92.7$ \\
\hline Class III & $3-5$ & $3-6$ & $25-50$ & $50-150$ & $0.3-0.9$ & $5-6$ & $51.9-76.5$ \\
\hline Class IV & $1-3$ & $6-12$ & $50-100$ & $150-300$ & $0.9-2.7$ & $<5$ & $31.0-51.9$ \\
\hline Class V & $<1$ & $>12$ & $>100$ & $>300$ & $>2.7$ & - & $<31.0$ \\
\hline & & & & & & & $\begin{array}{c}\text { Clean: } 81-100 \\
\text { Slightly polluted: } 60-80 \\
\text { Polluted: } 0-59\end{array}$ \\
\hline
\end{tabular}

Class I - Conservation of natural environment

Water Supply I - Practically no treatment necessary

Fishery I - Very sensitive aquatic species

Class II - Water Supply II - Conventional treatment

Fishery II - Sensitive aquatic species Recreational use body contact

Class III - Water Supply III - Extensive treatment required

Fishery III - Common economic value and tolerant species; livestock drinking

Class IV - Irrigation

Class V - None of the above
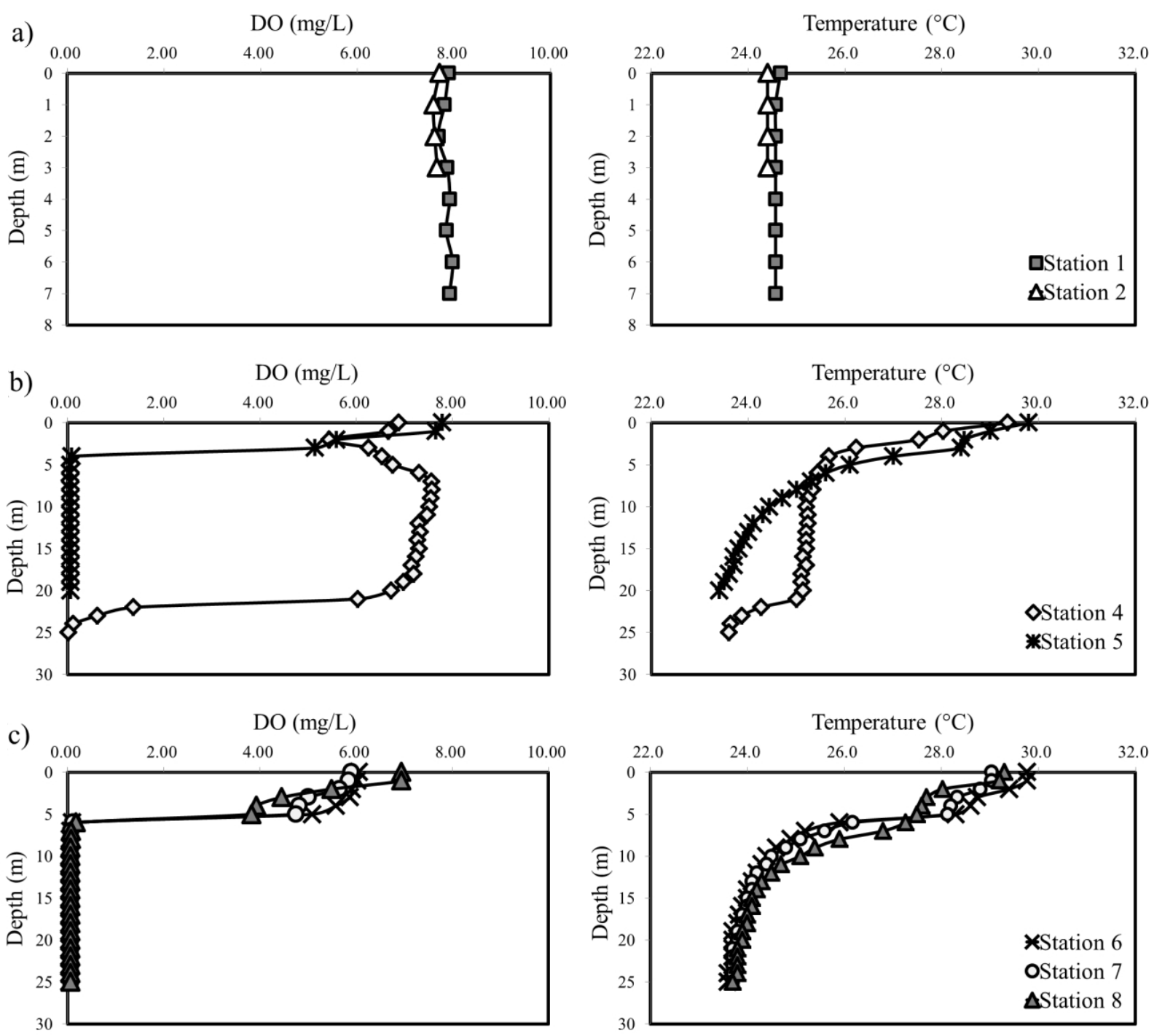

Fig. 2. Depth profiles of DO and temperature in a) riverine, b) transitional, and c) lacustrine zones in the Murum reservoir. 


\section{Statistical Analyses}

Comparison of water and sediment quality parameters between the functional zones in Murum Reservoir was conducted using one-way ANOVA and Tukey's pairwise comparisons with 5\% significance level. The Pearson's correlation analysis was performed to determine the relationship among the parameters for water and sediment samples. Cluster analysis was used to investigate the grouping of the sampling stations by using a total of 17 water quality parameters and a total of eight sediment quality parameters collected in the reservoir. Z-score standardization of the variables and Ward's method using Euclidean distances as a measure of similarity was used. The cluster was considered statistically significant at a linkage distance of $<60 \%$ and the number of clusters was decided by the practicality of the outputs [20]. All the statistical analyses were carried out using the Statistical Software for Social Sciences (SPSS Version 22, SPSS Inc. 1995).

\section{Results}

\section{Water Quality}

In the riverine zone, neither temperature nor $\mathrm{DO}$ was stratified vertically (Fig. 2). DO level of nearly $8 \mathrm{mg} / \mathrm{L}$ and a temperature of less than $25^{\circ} \mathrm{C}$ throughout the water column were observed at the riverine zone. However, noticeable vertical stratifications of DO and temperature were observed in the transitional and lacustrine zones in the reservoir. Station 4, located in the transitional zone, exhibited different trends of vertical stratifications of DO and temperature when compared to the other stations. The DO content decreased as depth increased up to $2 \mathrm{~m}$, but it started to rise after that and was maintained at more than $7 \mathrm{mg} / \mathrm{L}$ in the deeper water column. A sudden drop of DO content was then observed at a depth of $22 \mathrm{~m}$ where the DO was less than $2 \mathrm{mg} / \mathrm{L}$. However, at station 5 the DO content did not rise but dropped sharply to nearly zero at a depth of $4 \mathrm{~m}$. All three stations located in the lacustrine zone showed that DO content dropped to nearly zero at a depth of $6 \mathrm{~m}$. The difference among the three lacustrine stations was the thickness of the surface water column with DO content of more than $5 \mathrm{mg} / \mathrm{L}$, where it was $6 \mathrm{~m}$ at station 6 but $4 \mathrm{~m}$ and $3 \mathrm{~m}$ at stations 7 and station 8 , respectively. Similar to DO profile, temperature also decreased as depth increased in the transitional and lacustrine zones. Stations in the lacustrine zone were stratified into three distinct layers of different temperatures where the thermocline layer separates the epilimnion $\left(\approx 29^{\circ} \mathrm{C}\right)$ and the hypolimnion $\left(\approx 24^{\circ} \mathrm{C}\right)$. The thermocline started at a depth of 5-6 $\mathrm{m}$ and the temperature gradient within the thermocline layer was around $3-4^{\circ} \mathrm{C} / \mathrm{m}$.

The highest values of total discharge and mean velocity were observed at station 1 , which was located a)

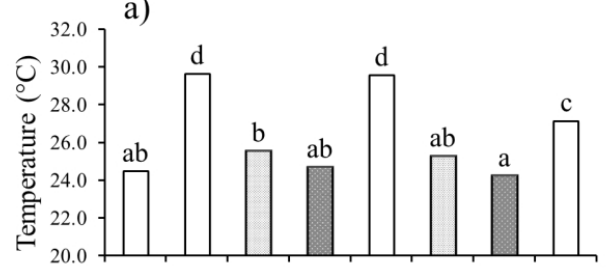

b)

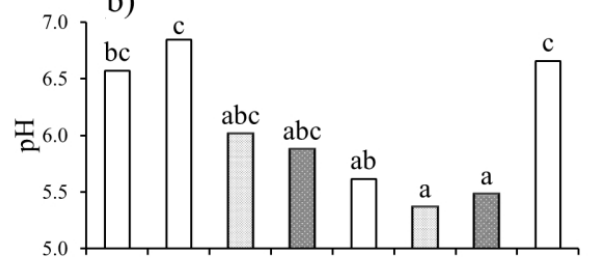

c)

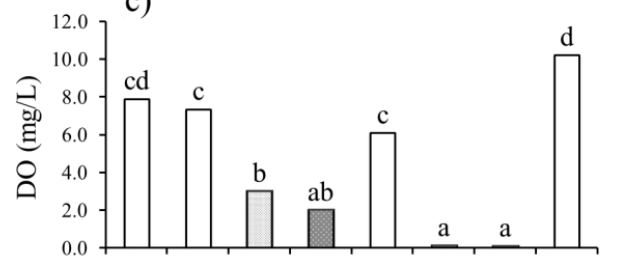

d)

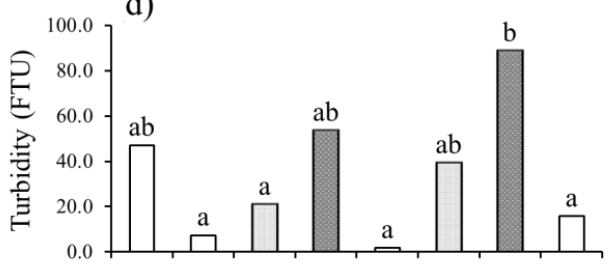

e)

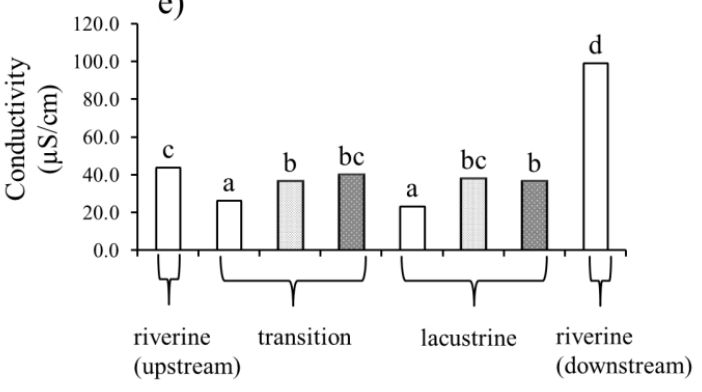

Functional zone

\section{Legend $\square$ Surface $\square 10 \mathrm{~m} \square 20 \mathrm{~m}$}

Fig. 3. In situ parameters of a) temperature, b) pH, c) DO, d) turbidity, and e) conductivity measured in different functional zones in the Murum reservoir (means with the same letters indicate no significant difference at 5\% level).

in the Plieran River. The results of ANOVA show that all of the in situ parameters demonstrated significant variations $(P \leq 0.05)$ among the different functional zones and water depths (Fig. 3). Surface water temperature was significantly higher in the transitional and lacustrine zones than in the riverine zone; and decreased significantly as depth increased $(P \leq 0.05)$. For surface $\mathrm{pH}$ value, significantly lower $\mathrm{pH}$ value was observed in the lacustrine zone than those in the riverine (downstream) and transitional zones $(P \leq 0.05)$. The $\mathrm{pH}$ value decreased as depth increased, but there 

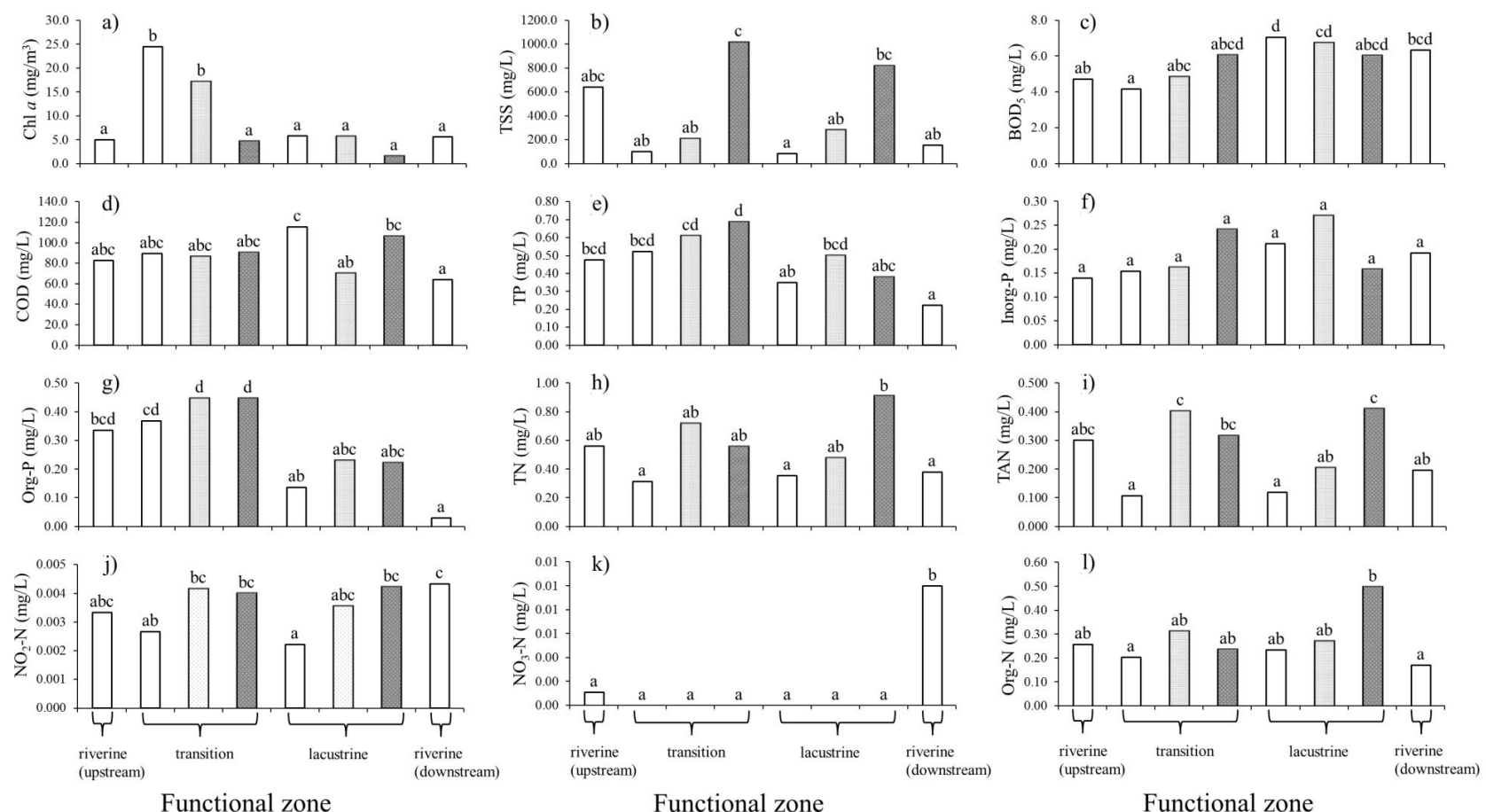

Legend $\square$ Surface $\square 10 \mathrm{~m} \quad \square 20 \mathrm{~m}$

Fig. 4. Mean water quality parameters of a) chl $a$, b) TSS, c), $\mathrm{BOD}_{5}$, d) COD, e) TP, f) Inorg-P, g) Org-P, h) TN, i) TAN, j) NO${ }_{2}-\mathrm{N}, \mathrm{k}$ ) $\mathrm{NO}_{3}-\mathrm{N}$, and 1) Org- $\mathrm{N}$ in different functional zones in the Murum reservoir (means with the same letters indicate no significant difference at $5 \%$ level).

was no significant difference between $\mathrm{pH}$ value at depths of $10 \mathrm{~m}$ and $20 \mathrm{~m}(P>0.05)$. Dissolved oxygen was high in the surface water of all zones. However, the DO content decreased significantly with depth $(P \leq 0.05)$, whereby at depths of $10 \mathrm{~m}$ and $20 \mathrm{~m}$ DO content was below $5 \mathrm{mg} / \mathrm{L}$ in the transitional zone and almost zero in the lacustrine zone. Significantly lower turbidity was observed in the surface water in the transitional, lacustrine, and riverine (downstream) zones than the $20 \mathrm{~m}$ depth of lacustrine zone $(P \leq 0.05)$. Similar to turbidity, conductivity increased as depth increased in the transitional and lacustrine zones. Conductivity was significantly higher in the riverine zone than the surface water of the transitional and lacustrine zones $(P \leq 0.05)$.

The ex situ water quality parameters analysis results are illustrated in Fig. 4. The surface chl $a$ concentration was significantly higher in the transitional zone than those in the other functional zones $(P \leq 0.05)$. In the transitional zone, chl $a$ concentration at the surface and $10 \mathrm{~m}$ depths were significantly higher than $20 \mathrm{~m}$ $(P \leq 0.05)$. The surface TSS concentration was the lowest in the lacustrine zone, whereas the highest was found in the riverine zone (upstream). TSS increased significantly as depth increased $(P \leq 0.05)$ where TSS concentrations at a depth of $20 \mathrm{~m}$ were $821.5 \mathrm{mg} / \mathrm{L}$ and $1019.0 \mathrm{mg} / \mathrm{L}$ in the lacustrine and transitional zones, respectively. Both $\mathrm{BOD}_{5}$ and COD did not show any significant difference between riverine (upstream) and transitional zones $(P>0.05)$.
The surface TP and Org-P concentrations steadily decreased from upstream to downstream direction, where significantly lower $(P \leq 0.05)$ surface TP and Org-P concentrations were found in the riverine (downstream) zone than those in the riverine (upstream) zone. The composition of TP also changed along the reservoir where Org-P was reduced from $71 \%$ in the riverine (upstream) zone to $14 \%$ of Org-P in the riverine (downstream) zone. However, the concentrations of Inorg-P were not significantly different among the different functional zones $(P>0.05)$, indicating uniform distribution $(\approx 0.19 \mathrm{mg} / \mathrm{L})$.

The surface TN concentration was significantly higher at $20 \mathrm{~m}$ than those in the transitional, lacustrine, and riverine (downstream) zones $(P \leq 0.05)$. In the lacustrine zones, mean TN concentrations increased significantly as depth increased with the highest value $(\approx 0.91 \mathrm{mg} / \mathrm{L})$ at $20 \mathrm{~m}$. TAN $(\approx 47 \%)$ and $\mathrm{Org}-\mathrm{N}(\approx 52 \%)$ were the primary forms of $\mathrm{TN}$, and the distribution patterns were similar to TN. The TAN was significantly higher at the deeper water columns of the transitional and lacustrine zones $(P \leq 0.05)$. Org-N concentration ranged from $0.17 \mathrm{mg} / \mathrm{L}$ to $0.50 \mathrm{mg} / \mathrm{L}$ with the mean significantly higher $(P \leq 0.05)$ at $20 \mathrm{~m}$ depth in the lacustrine zone than surface water of transitional and riverine (downstream) zones. Both $\mathrm{NO}_{2}-\mathrm{N}$ and $\mathrm{NO}_{3}-\mathrm{N}$ parameters showed low concentrations. The riverine zone in the downstream station contained the highest values of $\mathrm{NO}_{2}-\mathrm{N}(0.004 \mathrm{mg} / \mathrm{L})$ and $\mathrm{NO}_{3}-\mathrm{N}(0.01 \mathrm{mg} / \mathrm{L})$. 


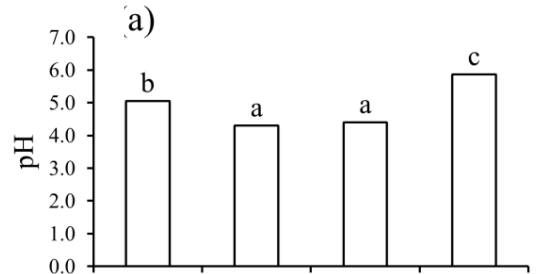

c)

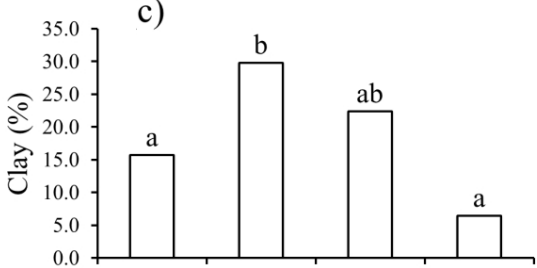

e)

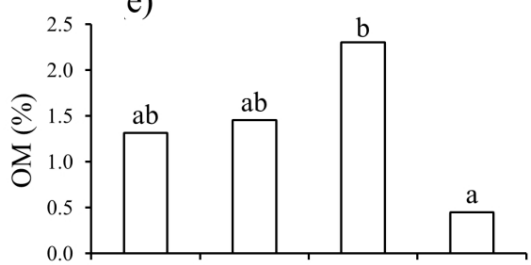

g)

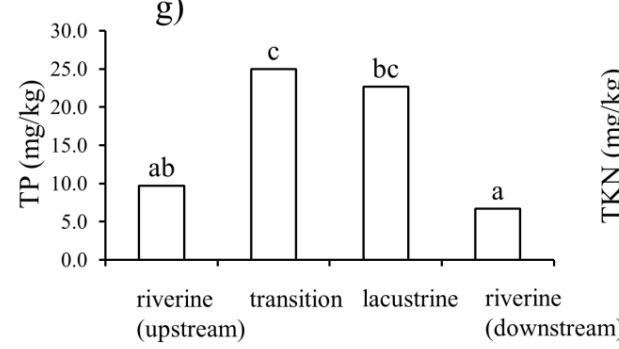

Functional zone

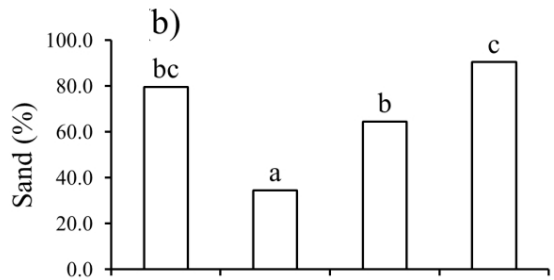

d)

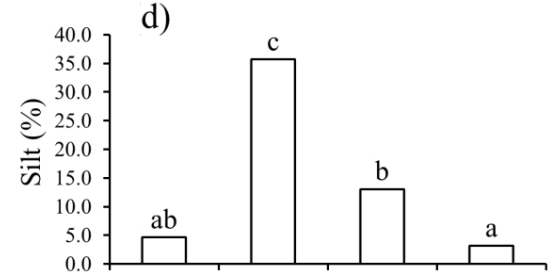

f)

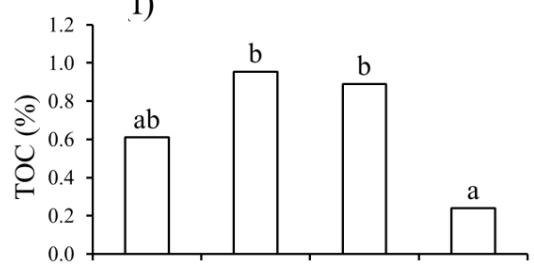

h)

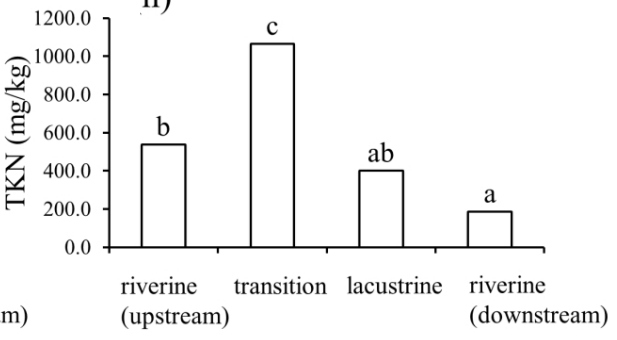

Functional zone

Fig. 5. Sediment quality parameters of a) $\mathrm{pH}$, b) sand, c) clay, d) silt, e) OM, f) TOC, g) TP, and h) TKN in different functional zones in the Murum reservoir (means with the same letters indicate no significant difference at $5 \%$ level).

$\mathrm{NO}_{2}-\mathrm{N}$ concentration was detected in surface water in all zones, where in the transitional and lacustrine zones it increased as depth increased, while $\mathrm{NO}_{3}-\mathrm{N}$ was undetectable in the transitional and lacustrine zones.

\section{Sediment Quality}

Sediment texture of the sampling stations in different functional zones in the Murum reservoir was mostly sand, ranging from $64.6 \%$ to $90.4 \%$, except for the transitional zone (Fig. 5). The soil texture in the transitional zone was significantly different from those in other functional zones $(P \leq 0.05)$ as it contained the lowest percentage of sand $(\approx 34.5 \%)$, but the highest percentage of silt $(\approx 35.7 \%)$ and clay $(\approx 29.8 \%)$. The silt and clay percentages in other functional zones ranged from $4.6 \%$ to $13.1 \%$ and $6.4 \%$ to $22.3 \%$, respectively. Besides the soil texture in the transitional zone, soil texture in the lacustrine zone was significantly different from the riverine (downstream) zone, where its sand percentage was significantly lower, while silt percentage was significantly higher than that in the riverine (downstream) zone $(P \leq 0.05)$. Sediment $\mathrm{pH}$ of the study area ranged from 4.3 to 5.9 , where significantly lower $\mathrm{pH}$ value was found in the transitional and lacustrine zones than the riverine zone $(P \leq 0.05)$. The OM content in the riverine (downstream) zone $(\approx 0.4 \%)$ was significantly lower than $\mathrm{OM}$ in the lacustrine zone $(\approx 2.3 \%)(P \leq 0.05)$. Similarly, the TOC content in the riverine (downstream) zone $(\approx 0.2 \%)$ was significantly lower than in the transitional $(\approx 1.0 \%)$ and lacustrine $(\approx 0.9 \%)(P \leq 0.05)$ zones. The highest sediment TP $(\approx 25.0 \mathrm{mg} / \mathrm{kg})$ and TKN $(\approx 1065.0 \mathrm{mg} / \mathrm{kg})$ were found in the transitional zone. Sediment TP was significantly higher in transitional and lacustrine zones than those in riverine zones, whereas sediment TKN was significantly higher in the transitional zone than those in all the other functional zones $(P \leq 0.05)$.

\section{Discussion}

Vertical stratifications of DO and temperature in reservoirs have been reported in tropical and subtropical reservoirs due to the lack of seasonal variation and weak 


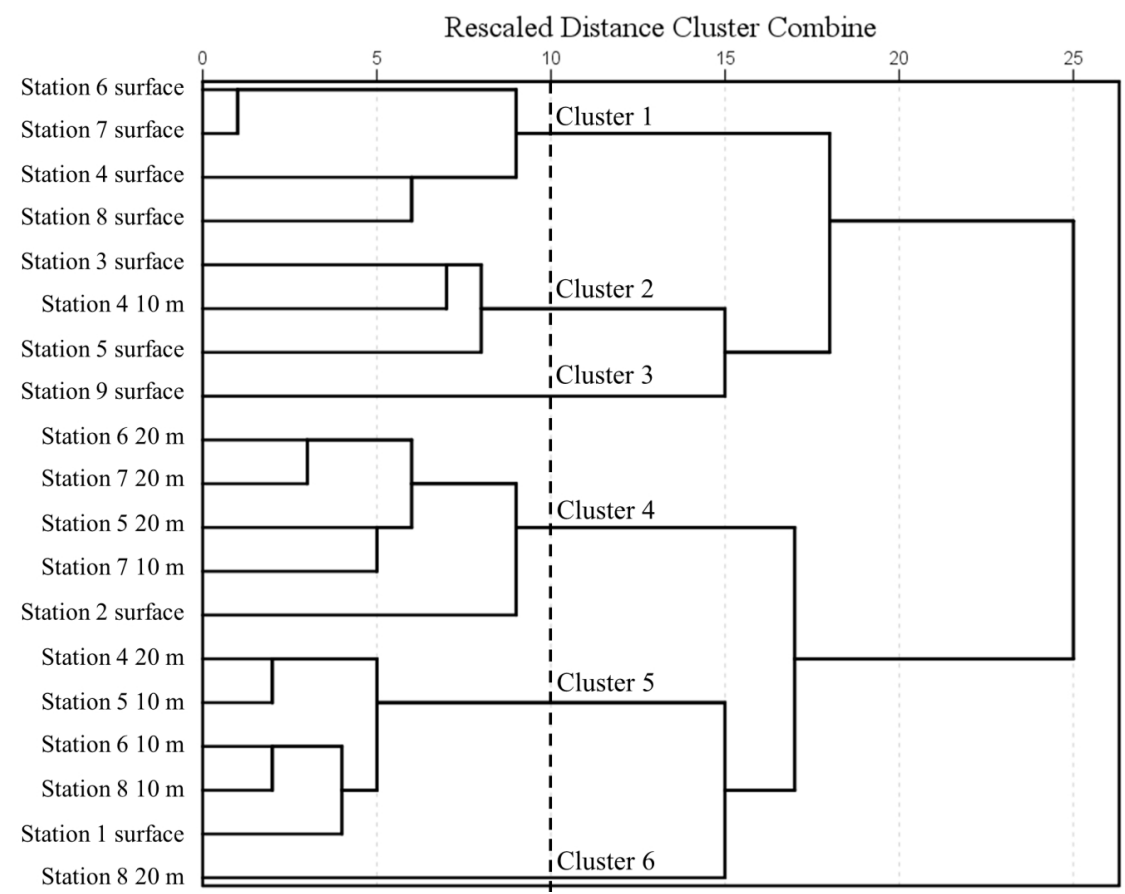

Fig. 6. Clustering of the Murum reservoir using the in situ and water quality parameters.

vertical mixing of water in the deep water column [21, 22]. In the present study, the Murum Reservoir exhibited distinct vertical stratifications of DO and temperature in the transitional and lacustrine zones during its filling stage, where similar observations were made by Angie et al. [23] in the Murum Reservoir two months before the present study. However, the fast-flowing riverine zone is well mixed and thus no vertical stratifications of DO and temperature were observed. Similarly, no thermal stratification was observed in the riverine zone of a recently refilled reservoir in Belgium [9]. In the lacustrine zone a healthy level of DO content (above $5 \mathrm{mg} / \mathrm{L}$ ) for aquatic organisms [24, 25] was only observed at the top $2-5 \mathrm{~m}$ of water column in the reservoir. The depth of water column that contained a healthy level of DO content decreased when the station was nearer to the dam. The thermocline in the lacustrine zone started at a depth of 5-6 m, which is similar to the study of Nyanti et al. [6], who reported that the thermocline started at a depth of 4-5 m in Bakun Reservoir during the filling phase.

Similar vertical stratification was recorded at station 5 in the transitional zone, where DO content dropped below $5 \mathrm{mg} / \mathrm{L}$ at a depth of $4 \mathrm{~m}$. However, station 4 , which was also located in the transitional zone exhibited different trends of vertical stratifications of DO and temperature because of different inflows. Stations 4 and 5 are receiving inflows from the Plieran and Danum rivers, respectively. The rapid water movement with a large volume of oxygenated colder water inflowing from the Plieran influences the depth profile at station 4 . The riverine inflow is influencing the deeper water column in the transitional and lacustrine zones as their density is greater than the surface water of the receiving system, and hence these inflows tend to plunge and enter as an interflow [26]. This is further supported by the results of the cluster analysis that grouped the surface water of upstream riverine zone together with the deeper water column of stations at transitional and lacustrine zones. Fig. 6 illustrates that all surface water columns were grouped as Clusters 1, 2, and 3, except the surface water in the upstream riverine zone. In particular, the turbidity value and TSS concentration in transitional and lacustrine zones at a depth of $20 \mathrm{~m}$ were found to be similar with those in the riverine zone, indicating the intrusion of the density current from the riverine zone into the transitional and lacustrine zones. The upstream river that contained high turbidity value and TSS concentration formed an interflow that intruded at a depth of $20 \mathrm{~m}$ in transitional and lacustrine zones, where the maximum turbidity and TSS layer were observed where the highest TSS exceeded $1000 \mathrm{mg} / \mathrm{L}$. The TSS concentration was extremely high when compared to Bakun Reservoir 13 months after reaching its full supply, where the highest TSS concentration was merely $167 \mathrm{mg} / \mathrm{L}$ at a depth of $30 \mathrm{~m}$ [27]. Hayami et al. [21] reported a similar interflow from the riverine zone to the hypolimnion layer of the lacustrine zone in an Indonesian reservoir. The authors also demonstrated the formation of local maxima of turbidity in the hypolimnion layer, which was due to the high turbidity in the river water. On the other hand, the local maxima of DO occurred at the transitional zone (station 4) but not at the lacustrine zone, indicating that the oxygen was exhausted during the intrusion as suggested by Hayami et al. [21].

The present study demonstrates that water quality of Murum Reservoir is different in different functional 
zones during the filling phase. The inflow from the riverine zone into the reservoir is often responsible for the longitudinal patterns observed in the reservoir transitional-lacustrine zone [4, 7]. Both upstream and downstream riverine zones of Murum Reservoir were higher in $\mathrm{pH}, \mathrm{DO}$, and conductivity, but lower in chl $a$ concentration than those in the transitional and lacustrine zones. On the other hand, TP and Org-P concentrations were significantly higher in upstream than those in downstream riverine zones. Also, turbidity, TSS, COD, TN, and TAN were relatively higher in the upstream riverine zone than the other functional zones in the surface water column. The high suspended solids and nutrients in the upstream riverine zone are most likely attributed to the oil palm plantation and logging activities in the watershed. Soil erosion and wastewater discharge from those anthropogenic activities coupled with the resuspension of sediment brought by the fast-flowing water increased the suspended solids and nutrients in the upstream riverine zone [28]. The high suspended solids $(\approx 212 \mathrm{mg} / \mathrm{L})$ and turbidity $(\approx 295 \mathrm{NTU})$ were prevalent in Plieran and Danum rivers long before the Murum Dam impoundment [29]. Nevertheless, nutrients in both rivers before impoundment [29] were relatively lower than those in the present study except for $\mathrm{NO}_{3}-\mathrm{N}(\approx 0.25 \mathrm{mg} / \mathrm{L})$, which became undetectable after impoundment. On the other hand, the $\mathrm{BOD}_{5}$ concentration gradually increased after impoundment where the $\mathrm{BOD}_{5}$ concentration that was initially less than $2 \mathrm{mg} / \mathrm{L}$ before impoundment [29] has been found ranging from $2.29 \mathrm{mg} / \mathrm{L}$ to $3.80 \mathrm{mg} / \mathrm{L}$ in the surface water eight months after impoundment [23], and more than $4 \mathrm{mg} / \mathrm{L}$ after 10 months of impoundment in the present study. Based on the preimpoundment study [29], the $\mathrm{NO}_{3}-\mathrm{N}$ concentration in the upstream riverine zone contributed more than $30 \%$ of TN in the year 2007 . However, the present study shows that it has decreased to less than $1 \%$ after the filling phase of the Murum Dam had commenced for 10 months. The changes in the nitrogen composition after the dam impoundment could be due to the accumulation of organic matter in the reservoir and slow nitrification rate as supported by the significantly higher sediment $\mathrm{OM}$ and TOC in lacustrine zone and TKN in transitional zone than the downstream river and the accumulation of ammonia in the deeper water column in transitional and lacustrine zones.

On the other hand, the riverine zone in the downstream area was significantly higher in surface water temperature and showed significantly higher conductivity, $\mathrm{BOD}_{5}$, and $\mathrm{NO}_{3}-\mathrm{N}$ than those in the upstream area, indicating that the outflow of the reservoir water is influencing the downstream river water quality. Fig. 6 illustrates that station 9 in the downstream riverine zone was grouped as cluster 3, suggesting that water quality in the downstream riverine zone has its distinct water quality characteristic compared to others. However, the downstream water quality was closely related to surface water from the upstream area as shown in clusters 1 and 2. This observation is similar to Bakun
Dam, which had been shown to play a significant role in regulating the water quality of its downstream river [30]. Water temperature in the upstream riverine zone is similar to that before impoundment of about $25^{\circ} \mathrm{C}$, but surface water at transitional and lacustrine zones $\left(>29^{\circ} \mathrm{C}\right)$ were much higher than the previous record, which ranged from $23.5^{\circ} \mathrm{C}$ to $26.0^{\circ} \mathrm{C}$ [29]. The surface water temperature in the transitional and lacustrine zone is much higher due to the direct solar radiation on the relatively stagnant water. The outflow of the high surface water temperature in the lacustrine zone thus substantially increased the water temperature in the downstream riverine zone $\left(\approx 27^{\circ} \mathrm{C}\right)$. In contrast, water temperature in the riverine zone was generally higher than the lacustrine zone in a recently refilled temperate reservoir in Belgium [9]. The $\mathrm{NO}_{3}-\mathrm{N}$ concentration was significantly higher in the downstream riverine zone than those in transitional and lacustrine zones due to the higher nitrification rate in well-oxygenated water. This observation is similar to the Saladito Reservoir in Cuba, where the organic matter was not transformed into $\mathrm{NO}_{3}-\mathrm{N}$ because of the large ammonium loads and lack of oxygen [31].

Acidification of reservoir water observed in the lacustrine zone ( $\mathrm{pH}$ value $\approx 5.5$ ) during the filling phase is most likely due to the decomposition of organic matter in an anaerobic condition [32]. The highest values of $\mathrm{BOD}_{5}, \mathrm{COD}$, and Org-N were observed in the lacustrine zone, indicating the accumulation of organic matter in the reservoir lacustrine zone. The acidification process was further supported by the significant negative correlation between $\mathrm{pH}$ and $\mathrm{BOD}_{5}(\mathrm{r}=-0.518, P \leq 0.05$, $\mathrm{N}=19$ ) and the significant positive correlation between $\mathrm{pH}$ and $\mathrm{DO}(\mathrm{r}=+0.634, P \leq 0.05, \mathrm{~N}=19)$, as shown in Table 4. Also, $\mathrm{pH}$ value rapidly decreased from 6.8 at surface water column to 6.0 at a depth of $10 \mathrm{~m}$ in the transitional zone. This substantial drop of $\mathrm{pH}$ value is most likely due to the saturated $\mathrm{CO}_{2}$ that is stored in the lower layer of the reservoir from decomposition below the thermocline [33-35]. A pH value as low as 4.1 was also observed at a depth of $20 \mathrm{~m}$ in the reservoir two months before the present study [23]. A similar observation was made in Bakun Reservoir during its filling phase, where the authors attributed the low $\mathrm{pH}$ value to the decomposition of submerged carbonaceous material and the release of acidic products in an inundated area [6]. The $\mathrm{BOD}_{5}$, TP, Org-P, TN, Org-N, TAN, and $\mathrm{NO}_{2}-\mathrm{N}$ increased as depth increased in the transitional zone in Murum Reservoir. Again, the high organic matter coupled with low DO led to the accumulation of TAN. Similarly, Zhu et al. [4] reported higher TN and TP concentrations at bottom water than those at surface water of the newly built Laohutan Reservoir during the initial impoundment period where the authors attributed the nutrient stratification to the release of soil nutrients.

Chl a concentration was found to be significantly higher in the transitional zone than that in the other functional zones. Light and nutrient limitations are 


\begin{tabular}{|c|c|c|c|c|c|c|c|c|c|c|c|c|c|c|c|c|c|c|c|}
\hline $\begin{array}{l}z_{1} \\
\text { s. } \\
0\end{array}$ & & & & & & & & & & & & & & & & & & & 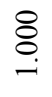 \\
\hline $\begin{array}{l}z_{1} \\
0^{\prime} \\
z^{2}\end{array}$ & & & & & & & & & & & & & & & & & & $\underset{-}{8}$ & $\frac{\partial}{9}$ \\
\hline $\begin{array}{l}z_{1}^{\prime} \\
0^{N}\end{array}$ & & & & & & & & & & & & & & & & & $\stackrel{8}{\circ}$ & 条 & $\begin{array}{l}\text { ते } \\
\text { ते }\end{array}$ \\
\hline Z & & & & & & & & & & & & & & & & $\underset{-}{\stackrel{8}{0}}$ & 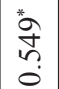 & $\begin{array}{l}n \\
\hat{o} \\
0 \\
i\end{array}$ & 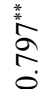 \\
\hline Z & & & & & & & & & & & & & & & 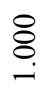 & 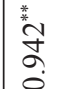 & $\underset{\tilde{q}}{\stackrel{\sigma}{0}}$ & \begin{tabular}{l}
$\tilde{n}$ \\
\hdashline \\
0
\end{tabular} & $\stackrel{*}{\hat{2}} \hat{\alpha}$ \\
\hline 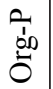 & & & & & & & & & & & & & & 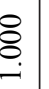 & $\stackrel{\text { f }}{\text { c. }}$ & oे & $\begin{array}{c}\vec{m} \\
\tilde{\vdots} \\
0\end{array}$ & $\begin{array}{c}\vec{r} \\
\tilde{0}\end{array}$ & 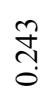 \\
\hline 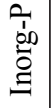 & & & & & & & & & & & & & $\dot{q}$ & $\begin{array}{l}0 \\
0 \\
0 \\
\\
\end{array}$ & $\frac{n}{i}$ & $\begin{array}{l}\vec{i} \\
\text { ஸे }\end{array}$ & $\begin{array}{l}8 \\
\vdots \\
0 \\
0\end{array}$ & $\begin{array}{l}a \\
\stackrel{1}{0} \\
1\end{array}$ & $\begin{array}{l}\text { do } \\
\stackrel{1}{1}\end{array}$ \\
\hline$\hat{F}$ & & & & & & & & & & & $\stackrel{\square}{~}$ & $\mathfrak{d}$ & & $\begin{array}{l}0 \\
\vdots \\
0 \\
0 \\
0\end{array}$ & 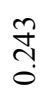 & 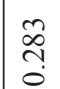 & $\begin{array}{c}\overrightarrow{7} \\
\stackrel{0}{0}\end{array}$ & $\mid \begin{array}{l}\infty \\
0 \\
+ \\
0 \\
0\end{array}$ & $\stackrel{2}{\stackrel{0}{0}}$ \\
\hline ชิ & & & & & & & & & & 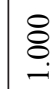 & đี & 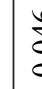 & 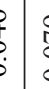 & 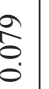 & 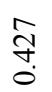 & $\begin{array}{l}\text { to } \\
\text { ç }\end{array}$ & 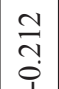 & $\begin{array}{l}\vec{i} \\
\vdots \\
0\end{array}$ & $\begin{array}{l}* \\
\tilde{n} \\
n \\
o\end{array}$ \\
\hline$\hat{O}^{n}$ & & & & & & & & & $\stackrel{8}{\circ}$ & $\underset{\infty}{\infty}$ & $\begin{array}{l}\text { qu } \\
0 \\
0\end{array}$ & c & & 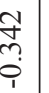 & $\begin{array}{l} \pm \\
\stackrel{0}{0} \\
\stackrel{0}{0}\end{array}$ & $\begin{array}{l}8 \\
0 \\
0 \\
1\end{array}$ & $\frac{2}{2}$ & $\frac{\widehat{a}}{0}$ & $\begin{array}{l}\infty \\
\hat{0} \\
0\end{array}$ \\
\hline $\begin{array}{l}\mathscr{D} \\
\omega \\
\Leftrightarrow\end{array}$ & & & & & & & & 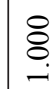 & 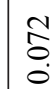 & ป̃ & $\begin{array}{l}\text { J } \\
0 \\
0\end{array}$ & $£$ & $\begin{array}{c}0 \\
\vdots \\
\vdots \\
\vdots\end{array}$ & $\begin{array}{l}\infty \\
8 \\
\\
\end{array}$ & $\frac{\text { In }}{0}$ & $\begin{array}{l}\text { กิ } \\
\text { ç }\end{array}$ & $\begin{array}{l}t \\
0 \\
0\end{array}$ & $\mid \begin{array}{l}m \\
\dot{0} \\
\dot{0}\end{array}$ & $\tilde{\delta}_{\dot{0}}$ \\
\hline$\stackrel{0}{\text { 궁 }}$ & & & & & & & $\stackrel{-}{\circ}$ & 袋 & $\begin{array}{l}\mathscr{\delta} \\
0 \\
0\end{array}$ & $\underset{\hat{\delta}}{0}$ & 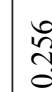 & 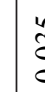 & 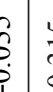 & $\begin{array}{c}n \\
\cdots \\
0 \\
0\end{array}$ & $\frac{q}{\stackrel{q}{0}}$ & $\stackrel{\infty}{=}$ & 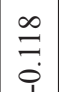 & $\begin{array}{l}1 \\
0 \\
0 \\
0\end{array}$ & $\stackrel{n}{0}$ \\
\hline$\stackrel{\varrho}{\exists}$ & & & & & & 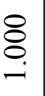 & $\begin{array}{l}0 \\
\tilde{n} \\
\tilde{n}\end{array}$ & $\begin{array}{l}\stackrel{*}{2} \\
\stackrel{\alpha}{0} \\
\stackrel{2}{0}\end{array}$ & ¿ & $\overrightarrow{\tilde{\sigma}}$ & $\mid \begin{array}{l}\infty \\
0 \\
0 \\
1\end{array}$ & 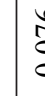 & م. & $\begin{array}{l}\vec{b} \\
\\
\\
\end{array}$ & 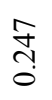 & 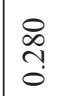 & $\mid \begin{array}{l}\infty \\
\infty \\
0 \\
0\end{array}$ & 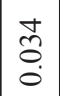 & $\frac{\bar{\sigma}}{0}$ \\
\hline $\overrightarrow{\tilde{U}}$ & & & & $£$ & & $\begin{array}{l}\stackrel{8}{0} \\
\stackrel{0}{0}\end{array}$ & 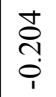 & $\begin{array}{l}8 \\
8 \\
0\end{array}$ & $\stackrel{\hat{o}}{0}$ & 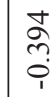 & $\begin{array}{l}\bar{\Xi} \\
\text { ç }\end{array}$ & 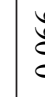 & $\begin{array}{l}0 \\
\vdots \\
\vdots \\
\vdots\end{array}$ & $\begin{array}{l}0 \\
0 \\
\\
\\
1\end{array}$ & $\begin{array}{l}\mathscr{0} \\
\ddot{0} \\
0\end{array}$ & $\frac{n}{0}$ & $\mid$\begin{tabular}{c}
0 \\
\multirow{2}{m}{} \\
0
\end{tabular} & $\mid \begin{array}{c}N_{0} \\
\infty \\
\infty \\
0\end{array}$ & $\begin{array}{l}\stackrel{8}{\circ} \\
\stackrel{\circ}{0}\end{array}$ \\
\hline ̊ & & & $\stackrel{8}{\circ}$ & $\begin{array}{l}\alpha \\
a \\
a \\
a\end{array}$ & & 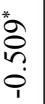 & $\underset{\hat{O}}{\hat{0}}$ & 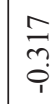 & $\stackrel{0}{\stackrel{0}{9}}$ & $\begin{array}{l}0 \\
0 \\
0 \\
i\end{array}$ & $\begin{array}{l}\tilde{n} \\
\tilde{c}\end{array}$ & $\begin{array}{l}5 \\
2 \\
2\end{array}$ & ?: & $\begin{array}{l}\text { ôे } \\
\text { cे } \\
\end{array}$ & $\begin{array}{l}\bar{n} \\
\stackrel{?}{?} \\
i\end{array}$ & $\begin{array}{l}0 \\
\text { ñ } \\
\text { ? }\end{array}$ & $\begin{array}{c}1 \\
m \\
0 \\
i\end{array}$ & $\begin{array}{l}n \\
n \\
\dot{\sigma} \\
0\end{array}$ & $\begin{array}{c}2 \\
\hat{n} \\
\hat{?}\end{array}$ \\
\hline 洁 & & $\stackrel{8}{\circ}$ & $\mid \begin{array}{l}4 \\
6 \\
0 \\
0\end{array}$ & $\frac{\curvearrowright}{9}$ & & $\begin{array}{l}n \\
\hat{o} \\
\dot{c} \\
i \\
i\end{array}$ & ํㅗㅁ & ठ̂. & 童 & ત્ઞ & $\stackrel{0}{\underset{1}{c}}$ & 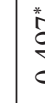 & 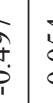 & $\begin{array}{l}0 \\
0 \\
0 \\
0\end{array}$ & $\begin{array}{c}\vec{n} \\
\text { ?̦ } \\
\text { i }\end{array}$ & $\begin{array}{l}n \\
\tilde{m} \\
\hat{i}\end{array}$ & $\mid \begin{array}{c}2 \\
\frac{\infty}{\dot{\varphi}} \\
\end{array}$ & $\begin{array}{c}\vec{\Xi} \\
\tilde{0} \\
0\end{array}$ & $\begin{array}{l}\text { ర్ } \\
\stackrel{1}{1}\end{array}$ \\
\hline 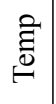 & $\underset{\Xi}{\stackrel{\Xi}{-}}$ & $\stackrel{3}{\stackrel{3}{0}}$ & $\begin{array}{l}\text { ồ } \\
\text { ஸे } \\
0\end{array}$ & ఏి & & $\begin{array}{l}8 \\
0 \\
0 \\
i\end{array}$ & I̊ & \begin{tabular}{l}
$*$ \\
\multirow{g}{g}{} \\
$\stackrel{9}{0}$
\end{tabular} & $\hat{o}$ & กิ & $\begin{array}{l}\text { : } \\
\text { ते }\end{array}$ & 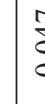 & t. & $\begin{array}{c}0 \\
\text { ch } \\
\text { i } \\
1\end{array}$ & $\begin{array}{l}\vec{J} \\
\stackrel{j}{i}\end{array}$ & 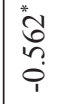 & 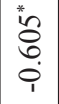 & $\begin{array}{l}0 \\
0 \\
0 \\
0\end{array}$ & $\begin{array}{l}a \\
0 \\
0 \\
i\end{array}$ \\
\hline & 害 & $\stackrel{\square}{2}$ & $\stackrel{\circ}{\circ}$ & $\bar{c}$ & 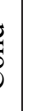 & 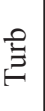 & $\frac{\sigma}{\frac{\pi}{0}}$ & $\mathscr{\mathscr { N }}$ & Оి & Оิ & $\hat{\varepsilon}$ & 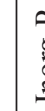 & 点 & 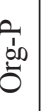 & $Z$ & $\underset{\sharp}{Z}$ & $\begin{array}{l}z_{1}^{\prime} \\
0^{N} \\
z^{2}\end{array}$ & $\begin{array}{l}Z_{1} \\
0^{\infty} \\
Z^{2}\end{array}$ & $\begin{array}{l}z \\
z \\
\text { bo } \\
0\end{array}$ \\
\hline
\end{tabular}


Table 5. Classification of water quality in different functional zones in the Murum reservoir according to WQI.

\begin{tabular}{|c|c|c|c|c|c|c|c|c|c|c|}
\hline Zone & Station & Water column & SIDO & SIBOD & SICOD & SISS & SIAN & SIpH & WQI & Class \\
\hline \multirow{3}{*}{$\begin{array}{c}\text { Riverine } \\
\text { (upstream) }\end{array}$} & 1 & Surface & II & III & IV & IV & III & $\mathrm{V}$ & III & Slightly polluted \\
\hline & 2 & Surface & I & III & IV & V & II & II & III & Slightly polluted \\
\hline & 3 & Surface & I & III & IV & I & II & I & II & Clean \\
\hline \multirow{6}{*}{ Transitional } & \multirow{3}{*}{4} & Surface & I & IV & IV & IV & II & II & III & Slightly polluted \\
\hline & & $10 \mathrm{~m}$ & II & III & IV & $\mathrm{V}$ & III & II & III & Slightly polluted \\
\hline & & $20 \mathrm{~m}$ & III & IV & IV & V & III & V & III & Polluted \\
\hline & \multirow{3}{*}{5} & Surface & I & II & IV & I & II & I & II & Clean \\
\hline & & $10 \mathrm{~m}$ & V & III & IV & III & III & V & IV & Polluted \\
\hline & & $20 \mathrm{~m}$ & V & III & IV & V & II & II & IV & Polluted \\
\hline \multirow{9}{*}{ Lacustrine } & \multirow{3}{*}{6} & Surface & II & III & V & I & I & V & II & Slightly polluted \\
\hline & & $10 \mathrm{~m}$ & V & IV & IV & IV & II & V & IV & Polluted \\
\hline & & $20 \mathrm{~m}$ & V & III & V & V & III & V & IV & Polluted \\
\hline & \multirow{3}{*}{7} & Surface & II & IV & V & IV & II & V & III & Slightly polluted \\
\hline & & $10 \mathrm{~m}$ & $\mathrm{~V}$ & IV & IV & IV & I & V & IV & Polluted \\
\hline & & $20 \mathrm{~m}$ & V & IV & IV & V & II & V & IV & Polluted \\
\hline & \multirow{3}{*}{8} & Surface & II & IV & V & III & II & V & III & Slightly polluted \\
\hline & & $10 \mathrm{~m}$ & V & IV & IV & $\mathrm{V}$ & III & $\mathrm{V}$ & IV & Polluted \\
\hline & & $20 \mathrm{~m}$ & $\mathrm{~V}$ & III & V & V & III & V & IV & Polluted \\
\hline $\begin{array}{c}\text { Riverine } \\
\text { (downstream) }\end{array}$ & 9 & Surface & I & IV & IV & IV & II & II & III & Slightly polluted \\
\hline
\end{tabular}

shown to inhibit phytoplankton growth in the riverine and lacustrine zones [8, 10]. Besides, Scott et al. [36] demonstrated that the nitrogen fixation rates in reservoir transitional zone were 25-60 times higher than those in riverine and lacustrine zones. The chl $a$ concentration in transitional zone decreased when depth increased as light limitation is affecting the growth of the phytoplankton in the deeper water

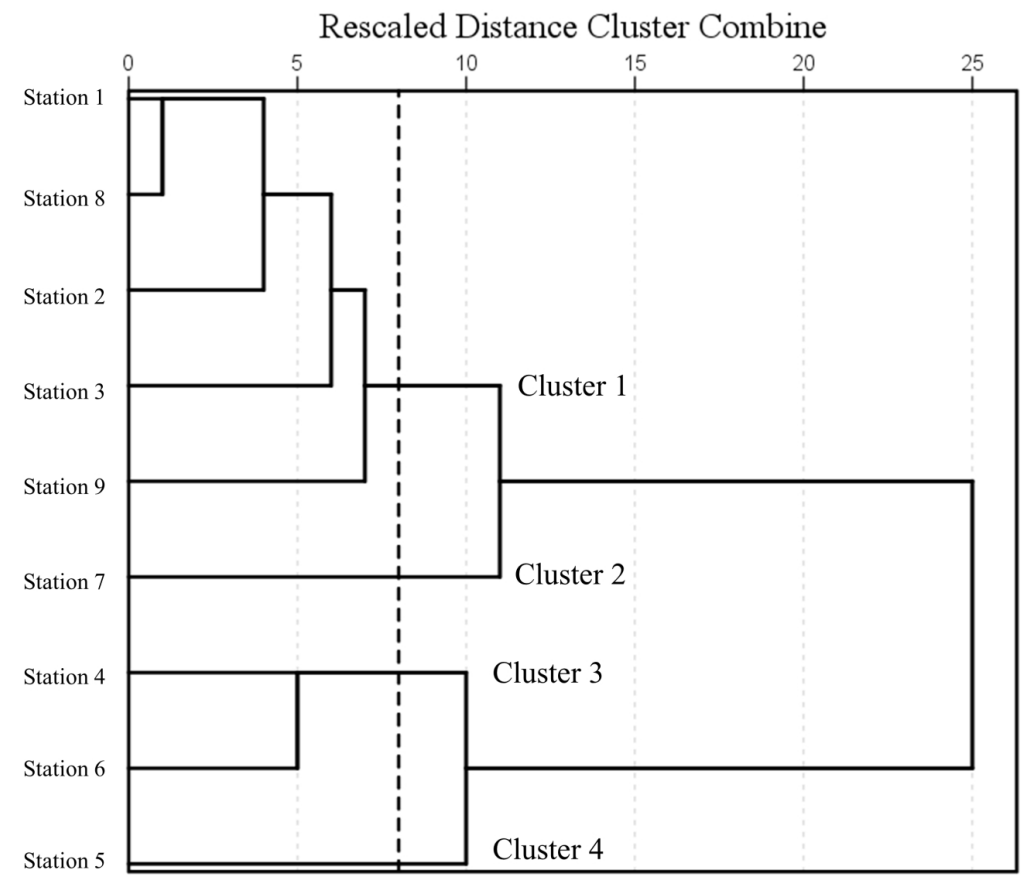

Fig. 7. Clustering of the Murum reservoir using the sediment quality parameters. 
Table 6. Correlation matrix of the sediment quality parameters in the Murum reservoir $(N=9)$.

\begin{tabular}{|c|c|c|c|c|c|c|c|c|}
\hline & $\mathrm{pH}$ & Sand & Clay & Silt & OM & TOC & TP & TKN \\
\hline $\mathrm{pH}$ & 1.000 & & & & & & & \\
\hline Sand & 0.647 & 1.000 & & & & & & \\
\hline Clay & -0.528 & $-0.882 * *$ & 1.000 & & & & & \\
\hline Silt & -0.630 & $-0.920 * *$ & 0.627 & 1.000 & & & & \\
\hline OM & -0.398 & -0.420 & 0.390 & 0.370 & 1.000 & & & \\
\hline TOC & -0.592 & -0.435 & 0.246 & 0.514 & 0.501 & 1.000 & & \\
\hline TP & $-0.713 *$ & -0.533 & 0.582 & 0.398 & 0.211 & 0.100 & 1.000 & \\
\hline TKN & -0.381 & $-0.817 * *$ & 0.661 & $0.802 * *$ & 0.202 & 0.157 & 0.184 & 1.000 \\
\hline
\end{tabular}

*Significantly different in $p$ value $\leq 0.05$

column where turbidity and TSS were higher than surface water. The low chl a concentration in the upstream riverine zone coincided with high turbidity and TSS, suggesting that phytoplankton in the area was limited by light availability. On the other hand, the chl $a$ in surface water of lacustrine zone remained low, although the surface turbidity and TSS were relatively low. The low chl $a$ concentration, however, coincided with low nutrient concentration, suggesting that nutrients were the limitation for phytoplankton in the lacustrine zone. Chl $a$ concentration in the transitional zone of Murum Reservoir $\left(\approx 15.5 \mathrm{mg} / \mathrm{m}^{3}\right)$ was relatively higher than that reported in Laohutan Reservoir [4], where it ranged from 1 to $10 \mathrm{mg} / \mathrm{m}^{3}$; whereas chl $a$ concentration in the lacustrine zone $(\approx 4.4$ $\mathrm{mg} / \mathrm{m}^{3}$ ) was within the reported range during its initial impoundment period. The higher chl $a$ concentration in the present study could be due to the considerably higher TP concentration in Murum Reservoir $(\approx 0.51$ $\mathrm{mg} / \mathrm{L})$ than in Laohutan Reservoir (0.013-0.073 mg/L), as phosphorus is often considered the limiting factor in phytoplankton growth.

The present study results show that the condition of Murum Reservoir was impaired during the filling phase. Table 5 shows that the WQI near Murum dam was good before the impoundment except for TSS [29]. Currently, only two stations were categorized as 'clean': station 3 located upstream of a tributary of the Danum River and station 5 in the transitional zone that received the inflow water from the Danum. The similar characteristics of these two stations were confirmed as they were categorized as the same cluster in cluster analysis (Fig. 6). Comparatively, the Plieran River was more polluted than the Danum, as most of the parameters were classified as Class III, IV, and/or $\mathrm{V}$ (Table 5). Anthropogenic activities from the riverine input are the main factors contributing to the water quality deterioration in the reservoir. The sedimentation, depletion of oxygen, and acidification in deeper water column in transitional and lacustrine zones further deteriorated the water quality of the reservoir.
The present study demonstrates that sediment quality in the Murum reservoir was altered during the filling phase, particularly in transitional and lacustrine zones. Cluster analysis indicated that sediment in transitional and lacustrine zones shared no similarity with sediment in riverine zones except station 8 (Fig. 7). The sediments in upstream and downstream riverine zones were categorized as the same cluster and shared similar characteristics. Sand is the major constituent of the sediment ranging from $94.8 \%$ to $99.0 \%$, while the rest are made up of silt in the study area before dam impoundment [29]. After dam impoundment, the soil texture in the riverine zone remained similar with high sand and low silt percentages, but clay was found in the sediment. The drastic change of sediment quality in the reservoir was the soil texture in the transitional zone, where it contained the lowest percentage of sand but the highest percentages of silt and clay. The sand and silt percentages in the lacustrine zone were also significantly different from the riverine (downstream) zone. When the upstream riverine inputs of water and sediment enter a reservoir, its velocity is reduced and the sediment load is deposited in the reservoir. The silt and clay are deposited in the transitional and lacustrine zones via turbidity current due to the density stratification in the reservoir. It is hypothesized that the turbidity current was dissipated before reaching the lacustrine zone, and hence the highest silt and clay percentages were observed in the transitional zone. The fact that station 8 , which was the furthest station from the upstream riverine zone, is being categorized in the same cluster as the riverine zone further supports the hypothesis. The increase in silt and clay percentages in transitional and lacustrine zones also led to the significant increases in OM, TOC, TP, and TKN in the sediment. This is further supported by the significant positive correlation between sediment TKN and silt $(\mathrm{r}=+0.802, P \leq 0.05$, $\mathrm{N}=9$ ), as shown in Table 6 . The changes in sediment texture in transitional and lacustrine zones also very likely led to a significant decrease in sediment $\mathrm{pH}$ value in transitional and lacustrine zones. $\mathrm{pH}$ has been shown 
to regulate the accumulation and release of phosphorus in sediment $[37,38]$. The present study shows that low sediment $\mathrm{pH}$ in transitional and lacustrine zones had significantly increased the accumulation of phosphorus in the sediment as supported by the significant and negative correlation between sediment $\mathrm{pH}$ and TP ( $\mathrm{r}=-0.713, P \leq 0.05, \mathrm{~N}=9$ ).

\section{Conclusions}

During the filling phase, Murum Reservoir exhibited distinct vertical stratifications of temperature and DO in transitional and lacustrine zones, which was absent prior to impoundment. The inflows from the upstream riverine zone influenced the water quality of the transitional and lacustrine zones in the reservoir by the intrusion of the density current as an interflow, while the outflow from reservoir influences the water quality in the downstream river. The nitrogen composition in the reservoir has changed from a high nitrate and low ammonia condition prior to impoundment to a low nitrate and high ammonia condition. The sediment quality in the reservoir was also altered during the filling phase. The sediment quality of upstream and downstream riverine zones remained similar except for the presence of clay after impoundment, while the soil texture in the transitional zone showed distinct low sand and high silt and clay percentages. Murum Reservoir exhibited a transitional zone maximum in algal biomass. Acidification was observed in the lacustrine zone and deeper water column of transitional zone due to the decomposition of high organic matter in anaerobic condition. The condition of Murum Reservoir was impaired during the filling phase, where most of the stations in different functional zones were categorized as either 'slightly polluted' or 'polluted' as compared to the 'clean' status before impoundment.

\section{Acknowledgements}

The authors are grateful for the financial support provided by the Sarawak Energy Berhad through grant No. GL(F07)/SEB/4C/2013(26) and the facilities provided by Universiti Malaysia Sarawak.

\section{Conflict of Interest}

The authors declare no conflict of interest.

\section{References}

1. BECK M.W., CLAASSEN A.H., HUNDT P.J. Environmental and livelihood impacts of dams: common lessons across development gradients that challenge sustainability. Int. J. River Basin Manag. 10 (1), 73, 2012.

2. CUNHA D.D.A. FERREIRA L.V. Impacts of the Belo Monte hydroelectric dam construction on pioneer vegetation formations along the Xingu River, Pará State, Brazil. Brazilian J. Botany. 35 (2), 159, 2012.

3. LI J., DONG S., LIU S., YANG Z., PENG M., ZHAO C. Effects of cascading hydropower dams on the composition, biomass and biological integrity of phytoplankton assemblages in the middle Lancang-Mekong River. Ecol. Eng. 60, 316, 2013.

4. ZHU L., JIANG C., ZHANG P., LI D., ZHU X. Eutrophication in the newly built Laohutan Reservoir during the initial impoundment period: the role of nutrient loading. Environ. Earth Sci. 74 (6), 4803, 2015.

5. RANGEL L.M., SILVA L.H.S., ROSA P., ROLAND F., HUSZAR V.L.M. Phytoplankton biomass is mainly controlled by hydrology and phosphorus concentrations in tropical hydroelectric reservoirs. Hydrobiologia. 693 (1), 13, 2012.

6. NYANTI L., LING T.Y., GRINANG J. Physico-chemical characteristics in the filling phase of Bakun hydroelectric reservoir, Sarawak, Malaysia. Int. J. Appl. Sci. Technol. 2 (6), 92, 2012.

7. ARAUJO F.G., DE AZEVEDO M.C.C., FERREIRA M.D.L. Seasonal changes and spatial variation in the water quality of a eutrophic tropical reservoir determined by the inflowing river. Lake Reserv. Manag. 27 (4), 343, 2011.

8. CUNHA D.G.F., CALIJURI M.D.C. Limiting factors for phytoplankton growth in subtropical reservoirs: the effect of light and nutrient availability in different longitudinal compartments. Lake Reserv. Manag. 27, 162, 2011.

9. LOURANTOU A., THOMÉ J.P., GOFFART A. Water quality assessment of a recently refilled reservoir: the case of Bütgenbach Reservoir, Belgium. Lakes Reserv. Res. Manag. 12 (4), 261, 2007.

10. PIMENTA A.M., ALBERTONI E.F., PALMA-SILVA C. Characterization of water quality in a small hydropower plant reservoir in southern Brazil. Lakes Reserv. Res. Manag. 17 (4), 243, 2012.

11. SOVACOOL B.K., BULAN L.C. Energy security and hydropower development in Malaysia: The drivers and challenges facing the Sarawak Corridor of Renewable Energy (SCORE). Renew. Energy. 40 (1), 113, 2012.

12. CHAPRA S.C. Surface Water-Quality Modeling; McGraw-Hill Inc: New York, USA, 844, 1997.

13. HACH. Hach Water Analysis Handbook; Hach Company: Loveland, Colo, USA, 1642, 2012.

14. APHA. Standard Methods for the Examination of Water and Wastewater, 22nd edition; American Public Health Association: Washington, DC, USA, 1496, 2012.

15. GEE G.W., BAUDER J.W. Particle-size analysis. In Methods of Soil Analysis. Part 1. Physical and Mineralogical Methods; Klute, Madison, Eds., Soil Science Society of America, American Society of Agronomy: Madison, WI, 383, 1986.

16. THOMAS G.W. Soil $\mathrm{pH}$ and soil acidity. In Methods of Soil Analysis. Part 3. Chemical Methods; Sparks, Page, Helmke, Loeppert, Eds., Soil Science Society of America, American Society of Agronomy: Madison, WI, 475, 1996.

17. NELSON D.W., SOMMERS L.E. Total carbon, organic carbon, and organic matter. In Methods of Soil Analysis. Part 3. Chemical Methods; Sparks, Page, Helmke, 
Loeppert, Eds., Soil Science Society of America, American Society of Agronomy: Madison, WI, 961, 1996.

18. KUO S. Phosphorus. In Methods of Soil Analysis. Part 3. Chemical Methods; Sparks, Page, Helmke, Loeppert, Eds., Soil Science Society of America, American Society of Agronomy: Madison, WI, 869, 1996.

19. DEPARTMENT OF ENVIRONMENT. Malaysia Environmental Quality Report 2014; Department of Environment: Kuala Lumpur, Malaysia, 162, 2015.

20. MUANGTHONG S., SHRESTHA S. Assessment of surface water quality using multivariate statistical techniques: case study of the Nampong River and Songkhram River, Thailand. Environ. Monit. Assess. 187 (9), 1, 2015.

21. HAYAMI Y., OHMORI K., YOSHINO K., GARNO Y.S. Observation of anoxic water mass in a tropical reservoir: The Cirata Reservoir in Java, Indonesia. Limnology. 9 (1), 81, 2008

22. ZHANG Y., WU Z., LIU M., HE J., SHI K., ZHOU Y., WANG M., LIU X. Dissolved oxygen stratification and response to thermal structure and long-term climate change in a large and deep subtropical reservoir (Lake Qiandaohu, China). Water Res. 75, 249, 2015.

23. ANGIE S., LEE N., LING T.Y., SIM S.F., JONGKAR G. Assessing water quality of Murum Reservoir halfway through impoundment. Sains Malaysiana. 46 (12), 2367, 2017.

24. FLORIDA DEPARTMENT OF ENVIRONMENTAL PROTECTION. Technical Support Document: Derivation of Dissolved Oxygen Crtieria to Protect Aquatic Life in Florida's Fresh and Marine Waters; Florida Department of Environmental Protection, Florida, 232, 2013.

25. KANSAS DEPARTMENT OF HEALTH AND ENVIRONMENT. Allowances for Low Dissolved Oxygen Levels for Aquatic Life Use; Kansas Department of Health and Environment, Kansas, 5, 2011.

26. LI X., HUANG T., MA W., SUN X., ZHANG H. Effects of rainfall patterns on water quality in a stratified reservoir subject to eutrophication: implications for management. Sci. Total Environ. 521-522, 27, 2015.

27. LING T. Y., NYANTI L., MUAN T., GRINANG J., SIM S. F., MUJAHID A. Physicochemical parameters of Bakun reservoir in Belaga, Sarawak, Malaysia, 13 Months after reaching full supply level. Sains Malaysiana. 45 (2), 157, 2016.

28. GAO Q., LI Y., CHENG Q., YU M., HU B., WANG Z., YU Z. Analysis and assessment of the nutrients, biochemical indexes and heavy metals in the Three Gorges Reservoir, China, from 2008 to 2013. Water Res. 92, 262, 2016.

29. CHEMSAIN KONSULTANT SDN BHD. EIA for the Proposed Murum Hydroelectric Project, Belaga District, Kapit Division, Sarawak; Sarawak Energy Berhad: Sarawak, Malaysia, 2008.

30. LING T.Y., SOO C.L., HENG T.L.E., NYANTI L., SIM S.F., GRINANG J. Physicochemical characteristics of river water downstream of a large tropical hydroelectric dam. J. Chem. 2016, 1, 2016.

31. AVERHOFF O.L., GÓMEZ A.B., RODRÍGUEZ DEL REY E., AGUIAR C.B., VILLAZÓN M.A. Chemical, physical and biological characteristics of Saladito Reservoir, Cienfuegos Province, Cuba. Lakes Reserv. Res. Manag. 12 (1), 43, 2007.

32. LING T.Y., GERUNSIN N., SOO C.L., NYANTI L., SIM S.F., GRINANG J. Seasonal changes and spatial variation in water quality of a large young tropical reservoir and its downstream river. J. Chem. 2017, 1, 2017.

33. ELCI S. Effects of thermal stratification and mixing on reservoir water quality. Limnology. 9 (2), 135, 2008.

34. ADAMCZYK E.M., SHURIN J.B. Seasonal changes in plankton food web structure and carbon dioxide flux from Southern California reservoirs. PLoS ONE. 10 (10), 1, 2015.

35. BARROS N., COLE J.J., TRANVIK L.J., PRAIRIE Y.T., BASTVIKEN D., HUSZAR V.L.M., DEL GIORGIO P., ROLAND F. Carbon emission from hydroelectric reservoirs linked to reservoir age and latitude. Nature Geosci. 4 (9), 593, 2011.

36. SCOTT J.T., STANLEY J.K., DOYLE R.D., FORBES M.G., BROOKS B.W. River-reservoir transition zones are nitrogen fixation hot spots regardless of ecosystem trophic state. Hydrobiologia. 625 (1), 61, 2009.

37. GAO L. Phosphorus release from the sediments in Rongcheng Swan Lake under different $\mathrm{pH}$ conditions. Procedia Environ. Sci. 13 (2011), 2077, 2012.

38. WU Y., WEN Y., ZHOU J., WU Y. Phosphorus release from lake sediments: Effects of $\mathrm{pH}$, temperature and dissolved oxygen. KSCE J. Civil Eng. 18 (1), 323, 2014. 